\title{
Paisajes, territorios y lugares de la niñez chilena durante la dictadura*
}

\section{Landscapes, Territories and Places of Chilean Children during the Dictatorship}

\author{
Patricia Castillo Gallardo \\ (D) 0000-0003-0165-2871 \\ Universidad Academia de Humanismo Cristiano, Chile \\ pcastillog@docentes.academia.cl
}

Miguel Roselló Peñaloza

(D) 0000-0001- 5567-5513

Universidad Academia de Humanismo Cristiano, Chile

mrosellop@docentes.academia.cl

\section{Marcelo Garrido Pereira \\ (D) 0000-0001-8905-8986 \\ Universidad Academia de Humanismo Cristiano, Chile \\ mgarrido@ academia.cl}

Resumen: Muy pocos han sido los autores de la historia de la infancia que han decidido darle un lugar de privilegio a las fuentes producidas por niños y niñas en la construcción de sus historias. Este artículo presenta un fragmento de un proyecto de investigación cuyo objetivo es indagar la experiencia de la niñez durante la última dictadura cívico militar en Chile. Para ello se analiza un corpus compuesto por producciones infantiles realizadas en el periodo y entrevistas retrospectivas realizadas con la finalidad de documentar el objeto. $\mathrm{El}$ análisis se centra en reconstruir el paisaje, territorio y lugar desde la perspectiva de la geografía crítica y humanista.

Palabras clave: historia; infancia; dictadura; Chile; cultura material.

* Este artículo es parte de los resultados preliminares del proyecto de investigación FONDECYT $\mathrm{N}^{\circ} 11140271$ dirigido por la autora principal. 
Abstract: Very few writers about the history of childhood have decided to focus on the sources produced by children in the construction of their stories. This article presents a fragment of a research project designed to explore children's experience during the last military-civic dictatorship in Chile. To this end, it analyzes a corpus of children's productions during this period and retrospective interviews carried out to document the object of study. The analysis focuses on reconstructing the landscape, territory and place from the perspective of critical and humanistic geography.

Key words: history; childhood; dictatorship; Chile; material culture.

Fecha de recepción: 30 de noviembre de 2016 Fecha de aceptación: 5 de marzo de 2018

\section{INTRODUCCIÓN}

Tos avances para instalar a la infancia como campo de la historia en AméLrica Latina y en el mundo han sido sumamente importantes para abrir en lo contemporáneo un debate respecto a la construcción de un nuevo trato entre generaciones; principalmente porque construir historia de la infancia es, en algún sentido, otorgarle la condición de ser un fenómeno sobre el cual se pueden proponer distintas lecturas -tanto diacrónicas como sincrónicas-, y que al tensionarse con otros discursos ${ }^{1}$ no sólo nos habla sobre los niños y las niñas y sus vidas concretas, sino que más bien, en esas intersecciones, la niñez se constituye en una especie de indicio que permite conjeturar el modo en que, por ejemplo, una sociedad se relaciona con lo "no productivo", con lo que considera "en desarrollo", con lo "frágil", o bien, con la conciencia moral que impone el pensamiento sobre el futuro.

En ese sentido, la historia de la infancia está constituida por un conjunto de importantes estudios (Ariès, 1973; DeMause, 1995; Pollock, 1990; Riché \& Alexandre-Bidon, 2005; Rodríguez \& Mannarelli, 2007; Rojas Flores, 2010; Sosenski y Albarrán, 2012) a través de los cuales se puede acceder a una escena en la que circula una serie de sentidos, ideales morales y estrategias políticas que de alguna forma han sido difíciles de aprehender en los estudios sobre familia, educación, etcétera.

${ }^{1}$ Por ejemplo, el discurso del desarrollo económico, o de la educación. 
Sin embargo, es difícil encontrar una historiografía cuyo centro esté en las prácticas y en las experiencias de la niñez (Sosenski, 2010; 2012), excepto las que recurren a las autobiografías -es decir, a la memoria- como fuente para ello (Rojas Flores, 2010). El que hoy sea posible plantear un debate desde la construcción de una historia de la infancia que toma por corpus los documentos creados por niños es el resultado del propio avance disciplinar (Albarrán, 2014; Castillo, 2015a; Castillo y González, 2015a, 2015b; Castillo y Peña, 2018; Castillo, Peña, González, Trujillo y Garrido, 2017; Simarro, 2015; Sosenski, 2016). Vale decir que fue necesario extraer las consecuencias políticas y teóricas de los mandatos legales, a través de los cuales la sociedad cristaliza una nueva forma de definir a los niños y niñas (convención de los derechos del niño, entre otros), para que las disciplinas, incluyendo la historia, se vieran obligadas a buscar nuevas formas, cada vez más complejas, de interpretar y analizar la vida cotidiana de la niñez y sus significaciones.

Este artículo se ha construido en torno a una investigación que de alguna forma intenta ser fiel al acontecimiento que demarca la exigencia de este nuevo trato con la niñez. En ese sentido, se buscó construir un relato acerca de los paisajes, territorios y lugares de la niñez durante la última dictadura cívico-militar en Chile a través del análisis de un corpus construido a partir de producciones creadas por niños entre 1973 y 1990 (dibujos, cartas, diarios de vida, tarjetas postales, etc.) ${ }^{2}$ El acudir a la geografía crítica para analizar este corpus diverso no es una cuestión antojadiza; en cierto modo busca reconocer/proponer el carácter espacializado de la experiencia infantil. Ello quiere decir que la experiencia de la niñez en cualquier época histórica está dialécticamente construida en relación 1) con el espacio físico y sus determinaciones económicas y materiales; 2) con el espacio político y sus tensiones respecto a lo posible y lo pensable en una determinada sociedad; 3 ) con el espacio afectivo y sus fronteras familiares y exogámicas.

${ }^{2}$ Dicho corpus es el resultado de una campaña en redes sociales y medios de comunicación que convocó a la población perteneciente a esas generaciones a recuperar sus producciones infantiles y digitalizarlas para la construcción de un archivo que estará disponible a través de internet para la comunidad académica en general. El archivo contiene 2500 producciones infantiles entre las que se cuentan cartas, tarjetas, diarios de vida y dibujos. Dadas las características del archivo, las conjeturas que podemos construir aluden a un disponible conjunto de experiencias que se sintieron convocadas ante la consigna "Infancia en Dictadura". Por esto último, la mayor parte de los archivos pertenece a niños que vivieron en familias que fueron de oposición a la dictadura, aunque ello no significa que hayan sido parte de algún grupo con una identidad política definida. 
En ese sentido, el encuentro entre la historia y la geografía resulta particularmente virtuoso, pues permite recuperar una dimensión sin la cual ninguna experiencia puede ser identificada -paisajes, territorios y lugares-, con sus respectivas fronteras, sendas y caminos.

Ahora bien, las categorías de la geografía crítica se han puesto en dialogo con una materialidad/fuente que también le es atípica. Se trata de objetos/producciones infantiles, es decir, todo registro en el que niñas o niños sean emisores de un mensaje -escrito u oral-, durante el periodo estudiado.

Dadas las características de los objetos mencionados (dibujos, cartas, postales, grabaciones de audio, textos producidos en el contexto escolar y familiar), la clasificación realizada subraya el carácter subjetivo de cada producción; para ello hemos distinguido cada objeto según el receptor real o imaginado que inspira/motiva la producción analizada (Castillo, 2015a). Este, entre otros criterios, corresponde a una lógica que se ha dejado guiar por lo que Leonor Arfuch (2010) denomina la "voz enunciativa", que asume que "la situación de enunciación y el otro, el interlocutor, impondrán una forma del relato que es la que hará justamente a su sentido" (p. 27).

Asimismo, con la finalidad de fortalecer el archivo y el rescate de esta fuente de memoria, se hicieron entrevistas a quienes prestaron/donaron objetos. Dichas entrevistas devinieron herramienta de registro de los objetos para el catálogo/archivo a estructurarse como una herramienta metodológica que permite recuperar algunos aspectos de las memorias de la niñez que con una entrevista retrospectiva no habrían aparecido y que corresponden quizás a lo que Jean Claude Abric (2005) denominó "la zona muda de la representación" (p. 59).

En términos metodológicos, este estudio se inscribe en la investigación social cualitativa, siendo de carácter exploratorio y comprensivo. Se utilizó un enfoque discursivo, asumiendo que el discurso consiste en una práctica creadora de la realidad social (Potter, Wetherell y Wetherell, 1987). Específicamente se focaliza en la reconstrucción de los discursos enunciados por los protagonistas niños (retrospectivamente) registrados en sus producciones infantiles y recuerdos de infancia (Castillo et al., 2017). Desde la historiografía esta metodología de investigación podría ser considerada como "una estrategia basada en la utilización y confrontación de diversos tipos de fuentes, de acuerdo con las distintas dimensiones de los acontecimientos en estudio" (Milos, 2007, p. 22). Ello se justifica pues en este caso, al igual que en otros estudios que involucran historia y memoria, se requiere incrementar 
el conocimiento existente sobre el tema a través de la inclusión de fuentes no tradicionales. De esta manera, la elección de fuentes diversas es más bien un imperativo, pues de otro modo no es posible rescatar los elementos subjetivos que constituyen la memoria colectiva y que son la parte más significativa de este estudio (Rousso, 2012).

Este artículo desarrollará primero algunas nociones de la geografía crítica y la distinción entre paisaje, territorio y lugar. Luego presentará una breve contextualización respecto al espacio de los niños en Chile entre 1973 y 1990 según las instituciones que los rodean y, finalmente, se presentarán registros de la investigación organizados bajo los tres conceptos geográficos previamente distinguidos y se concluirá en torno a ellos.

\section{La dimensión geográfica de la experiencia infantil}

Desde la perspectiva de los estudios de la niñez resulta importante considerar los aportes de la geografía, en particular de la geografía crítica, es decir, aquella que define el espacio geográfico fundamentalmente como un espacio existencial (Nogué, 2014, p.159). Ello permitirá añadir profundidad a la reflexión respecto a la experiencia infantil, la cual sólo existe de forma espacial y en relación con los distintos paisajes y lugares en los que social y recíprocamente los propios niños se constituyen y recrean.

Dentro de las discusiones más importantes que se han dado al respecto en los últimos años, una de las más conflictivas es la referida a la distinción entre espacio y lugar (Tuan, 2007), pues de algún modo esta distinción permite alojar una dicotomía entre el espacio significado o en el que reside la identidad, y aquello que correspondería a la idea de fondo de esta identidad, que en ocasiones se entiende como perfectamente separada y distinguible (Davidson, Bondi, Smith, 2005). En el caso de la niñez, está división contribuye de manera dramática a la individualización de las experiencias infantiles, desplazando la cuestión afectiva e identitaria a un asunto familiar o, peor aún, de carácter individual.

En ese sentido, en la geografía Doreen Massey (2004) advierte sobre la "romantización de lo local", y desnuda cómo esta contribuye a la desresponsabilización política respecto a lo global. En ese marco, no está de más aclarar que este trabajo se instala desde un lugar crítico frente a esta dicotomía y considera la noción de espacio como apertura, movimiento, conflicto y diferencia. 
Ahora bien, aun sabiendo que de lo que se trata es de una escena fractal, en la que es imposible distinguir compartimientos, reubicaremos las categorías paisaje, territorio y lugares (Santos, 2000) por considerarse que dichas distinciones no se articulan como compartimientos estancos sino como claves que permiten conjeturar un recorrido por los elementos que atraviesan la cuestión identitaria y nutren la subjetividad desde el espacio social.

El paisaje, entonces, estaría constituido por todos los discursos que intervienen en la coloración de la realidad social y política que se habita cotidianamente. En dicho paisaje es posible distinguir materialidades y formas cuyo dibujo viene gestándose desde hace mucho tiempo, permitiendo la aparición de formaciones que se presentan como nuevas pero que tienen un proceso largo del cual dar cuenta. En el caso de la infancia es evidente que las transformaciones en las propias representaciones de esta vienen formándose y transformando el horizonte de las prácticas parentales desde antes del golpe de Estado (1973). Bajo ese nuevo escenario político, dichos elementos del paisaje son interpretados y conducidos hacia otro objetivo, uno en el que el lugar prioritario de la subjetividad infantil sirve de materia prima para lo que hoy puede denominarse como niño-sujeto-consumidor. Sin embargo, ese paisaje en tanto conjunto de formas que expresan la herencia de las transformaciones sucesivas de las relaciones entre adultos y niños puede ser reinterpretado para dar lugar a un verdadero reconocimiento del protagonismo infantil.

El territorio, por tanto, corresponde a una construcción histórico social que sintetiza las relaciones de poder en un determinado espacio geográfico (Souza, 1995, p.78). Siendo así, resulta evidente que tenemos más de un tipo de relación de poder disputándose en un mismo territorio: el poder político, el poder generacional, el poder entre semejantes. Siguiendo esta línea, la escena familiar es el territorio en disputa y lo familiar no encuentra su límite en lo consanguíneo, sino en el aprendizaje de los códigos bajo los cuales se determina lo ético en la identidad de cada grupo social específico. "Nosotros" como ese territorio político en el cual encontramos el reconocimiento histórico de cada experiencia vivida (Castillo y González, 2015a).

Finalmente, el "lugar" define la relación afectiva entre el individuo y ese territorio ya descrito. Es aquí en donde nuestros testigos depositan, construyen y problematizan la información adquirida, dudan, interpelan, preguntan, redefinen y finalmente construyen un sentido propio acerca de lo visto y lo oído. Los lugares "son porciones del territorio imbuidas de significados, de emociones y, por lo tanto, llenas de significados para los seres 
humanos" (Nogué, 2014, p. 159). Tan propio que a veces puede ser irreconocible para los familiares. En cierta forma, los testimonios sobre el lugar en la niñez permiten ilustrar el protagonismo insospechado de los niños-testigos, los cuales no son ni de cerca un simple y puro resultado de las influencias que pugnan por (in)formarlos.

\section{FORMAS DEL PAISAJE DE LA NIÑEZ EN CHILE (1973-1989)}

El golpe militar se produce en Chile el 11 de septiembre de 1973 y con él se constata, dramáticamente para la ciudadanía, que la división de clases era un escollo imposible de superar para la sociedad chilena y que las elites, ante cualquier amenaza a sus privilegios, estaban dispuestas a hacer valer su poder, sembrando terror, dolor y miseria.

El golpe militar en Chile afectó directa e indirectamente a muchos niños, algunos fueron víctimas de la tortura, la desaparición y la ejecución políti$\mathrm{ca}$, mientras que otros vivieron el horror del castigo a sus familiares, vecinos y amigos (Verdejo, Maureira y Dalla Porta, 2014, 2015). Los 17 años de dictadura se marcaron en los cuerpos de la niñez no sólo en lo que respecta al vulnerado derecho a la vida, sino también a las brutales transformaciones económicas y socioculturales que se produjeron durante este periodo y que modificaron para siempre el espacio en todas las dimensiones posibles (Errázuriz, 2009).

Ahora bien, se hace particularmente difícil encontrar una reconstrucción historiográfica de la niñez bajo la dictadura. La mayor parte de los trabajos disciplinarios desde los cuales es posible observar la vida cotidiana de la época, analizan y recopilan hechos relacionados con los partidos $\mathrm{u}$ organizaciones políticas (Álvarez Vallejos, 2003; Moyano Barahona, 2009; Palma Salamanca, 1997; Sandoval Ambiado, 2004), o bien con las experiencias con los dirigentes -hombres o mujeres- (Vidaurrázaga Aránguiz, 2006) y grupos más relevantes en la resistencia (Magasich-Airola, 2008) o con los aparatos de seguridad (Rebolledo, 2012). La vida de los niños quizás podría ubicarse entre esos espacios o recuentos, sin embargo, así se hace difícil describir, encontrar evidencia y dar verosimilitud a ese evanescente espacio de la niñez que creció bajo la dictadura y cuya vida, de una u otra manera, se fue impregnando de la "resaca histórica"(Salazar, 2006) de un conflicto cuyas consecuencias en la subjetividad nacional aún no terminamos de extraer. 
Aun así, podemos encontrar una serie de tópicos (Rojas Flores 2010) que pueden ayudar a entender las formas del paisaje de la niñez bajo la dictadura y sobre las que las investigaciones de los últimos años han permitido aportar nuevos elementos (Castillo, 2015a; Castillo y González, 2015a, 2015b; Llobet, 2015a, 2015b; Sosenski, 2005)

Una primera forma insoslayable es la que señala a la niñez como víctima directa de la represión por parte del Estado. Es decir, los niños como objeto de terror. Para ello, Jorge Rojas Flores (2010) consigna testimonios, informes de organismos internacionales y nacionales, así como también los de instituciones que se constituyeron para asistir a las víctimas de las violaciones a los derechos humanos. Con ello se dimensiona el impacto directo que tiene el golpe de Estado sobre un grupo específico de niños y niñas que fueron física y psicológicamente dañados por el Estado. Posteriormente, es posible encontrar una aproximación en cifras a través del trabajo de la Fundación para la Protección de la Infancia Dañada por los Estados de Emergencia (en adelante PIDEE), $u$ otros organismos nacionales, con las cuales se puede distinguir el impacto de la violencia en la niñez en relación directa con la clase social, etnia y otros elementos estructurales que forman parte de la victimización que, si bien se localiza contingentemente en relación con el golpe de Estado, tiene al menos un siglo y medio de gestación.

Sin embargo, no fue hasta los años sesenta que en Chile los niños adquieren una importancia ideológica de la magnitud que le asigna la junta militar a este tópico. La intervención de las prácticas culturales y educativas fue una tarea concertada y establecida como prioritaria desde un primer momento. La instauración de una ritualidad cívico-militar transformó considerablemente las vidas sociales de los niños. Ello significó la incorporación de niños y niñas en constantes ceremonias en torno a hitos y personajes del ejército de Chile así como a los valores patrios representados en el homenaje al folclore nacional y juegos tradicionales. Dicha intervención en la cotidianidad infantil se justifica en el supuesto de la disputa cultural por la conciencia de las nuevas generaciones y la legitimación del nuevo orden y sus acciones. ${ }^{3}$

${ }^{3}$ Esto coincide con lo planteado por Verónica Valdivia Ortiz de Zárate $(2010,2006)$ respecto a la relación de la dictadura militar con los sectores populares y la figura de "guerra declarada al marxismo" como argumento para la resocialización de los sectores populares. Asimismo, Errázuriz (2009) identifica las medidas mencionadas como parte del "golpe estético cultural" que se impone a toda la población en este escenario de disputa ideológica. 
En esta escena de disputa cultural y justificación ideológica del régimen dictatorial, las instituciones uniformadas, específicamente carabineros, se colocan como la figura de mayor cercanía a la escena infantil y familiar, representantes del cuidado, la seguridad pública, el sentido cívico y la protección del más débil (Castillo et al., 2017). Esta imagen se materializa en la creación de las brigadas escolares del tránsito, dispositivo que incorporaba a los escolares en el aprendizaje y resguardo del respeto de las normas de tránsito y que rápidamente instauró entre los participantes una diferencia de estatus, reconocimiento y poder, demarcando así un ideal claro de comportamiento cívico infantil (Rojas Flores, 2010).

Paralelamente, en torno a la infancia se crea una red institucional de beneficencia, que ya era parte del paisaje antes del golpe militar, pero que se acrecienta durante el tiempo de la dictadura. Los niños como objeto de las acciones filantrópicas permitieron la emergencia de varias entidades, algunas fuertemente vinculadas a las instituciones armadas (Fundación con la Discapacidad Intelectual, CoAnIL, y Corporación de Ayuda al Menor, CoRDAM), cuyo discurso se vinculaba rápidamente con el de la Junta Militar y la legitimación de sus acciones, y otras entidades que permanecieron al margen y que se articularon en torno a redes internacionales (Corporación Nutricional pro ayuda a niños y niñas, Conin, Corporación de Ayuda al Niño Quemado, CoAniQuen). Sin embargo, la más importante de estas iniciativas fue sin duda "Teletón", evento anual en beneficio de los discapacitados que tuvo un papel central en la metabolización de mensajes de unidad nacional que se evocaron con diversos usos a lo largo del periodo.

\section{Paisajes: la niñez etnógrafa}

Los niños y niñas que vivieron el periodo de la dictadura fueron testigos de los elementos del paisaje que la sociedad de Chile no logró resolver en todos sus años de historia republicana (Castillo, 2015b). Es decir, en ese duro tránsito de pasar de colonia española a república en vías de desarrollo, el país no logró corregir desigualdades estructurales y estructurantes; de alguna manera, la dictadura militar de 1973 se instaló, a nivel discursivo, como una suerte de ejemplo brutal respecto a lo que puede llegar a suceder en caso que dicho ordenamiento pudiese llegar a conmoverse (Castillo, 2015b). Es así como algunos niños y niñas profundamente afectados por la pobreza y la desigual- 
dad, partícipes por decisión de sus padres de un discurso con un marcado compromiso ideológico con la resistencia, narran a través de sus producciones los elementos que hemos de considerar como parte del paisaje, pues pese a que en muchas de esas producciones se identifique claramente al dictador Pinochet como el responsable de la situación, también es cierto que la historia económica de Chile tiene muchos otros indicadores que nos permiten afirmar que dicha situación de desigualdad precede y sucede al dictador.

La cesantía, la pobreza y la desigualdad son tópicos que adquieren formas distintas pero que insisten en las producciones infantiles y en las entrevistas aparecidas en los documentales realizados directamente en la época. ${ }^{4}$

El dibujo de Fidel y Elisabeth (véase imagen 1) es particularmente interesante en esta materia, pues corresponde a niños que realizan estas creaciones respondiendo a una consigna de la institución en la que se les solicita que escriban o grafiquen sus deseos de fin de año. Este trabajo, correspondiente al año 1986, involucra sólo a niños que se encuentran en procesos reparatorios en el organismo debido a que, por acción del Estado, alguno de sus familiares ha sido afectado por la prisión política, el exilio o la desaparición forzada. En ese sentido, resulta interesante constatar que varias de las producciones que la organización archiva respecto a esta actividad remiten específicamente a este tema, el cual se superpone a los dolores singulares que cada quien tuvo/ tiene según su pérdida individual. Esto también ocurre en los dibujos resguardados por la fundación entre niños los cuales consisten en reacciones al taller de trabajo afectivo en sectores desfavorecidos de la zona sur de Santiago (véanse imágenes 2 y 3 ).

De algún modo, se observan con claridad las enormes dificultades económicas que atravesaron las familias y el modo en que los niños y niñas testifican sobre ellas. En ese plano podemos ubicar una continuidad entre estos fenómenos desde los elementos descritos previamente respecto a la historia de la república. Sin embargo, también podemos señalar ciertas particularidades con las cuales la percepción infantil aporta otra coloratura al paisaje que describe. Si observamos la imagen 2 podemos notar lo significativo que resulta en la descripción de la desigualdad la distribución de la belleza, de la naturaleza, es decir, la desigualdad y la pobreza no sólo se describen en

${ }^{4}$ Los niños prohibidos (1986), documental de Augusto Góngora; Cien niños esperando un tren (1988), documental de Ignacio Agüero 

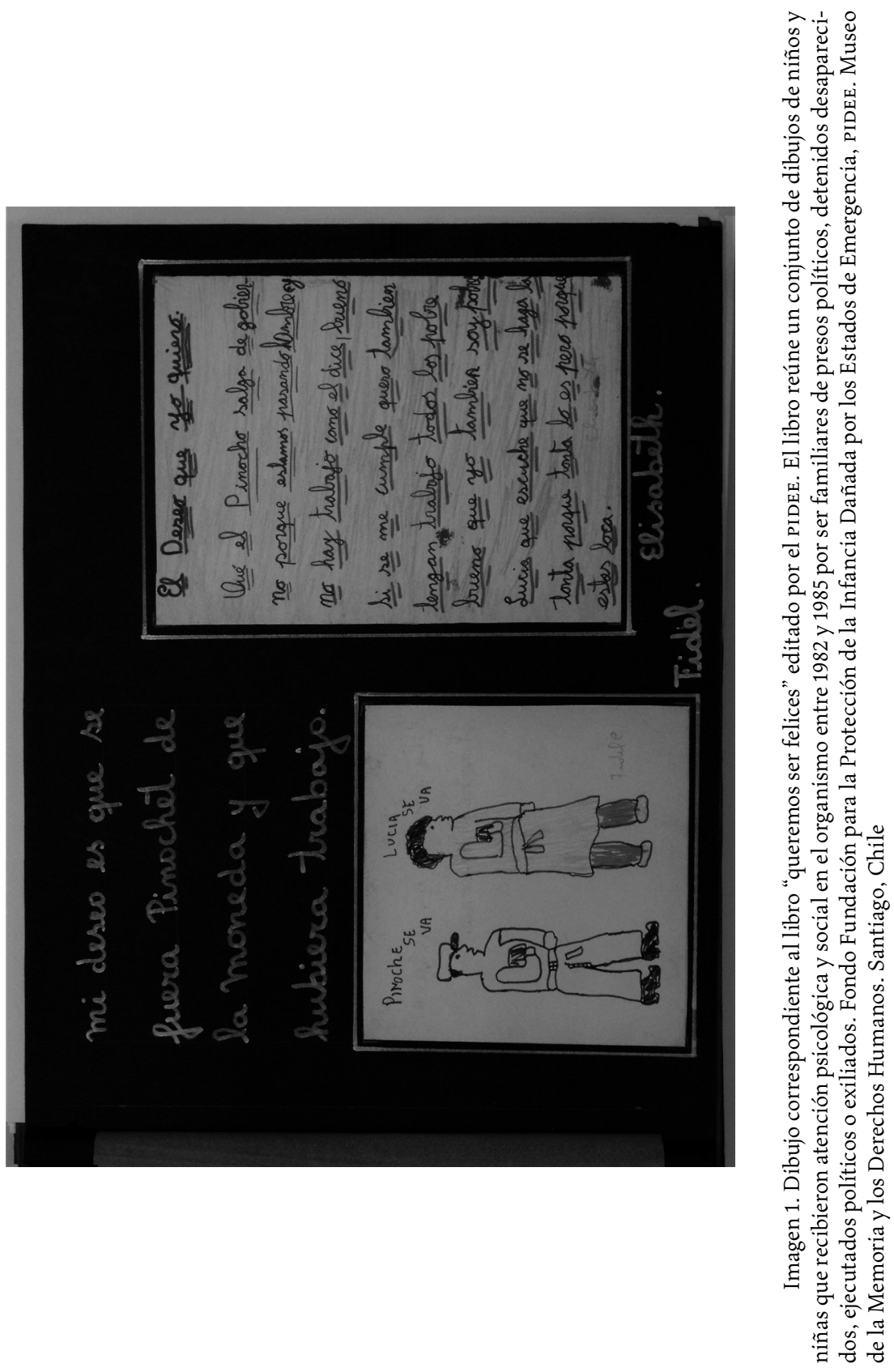


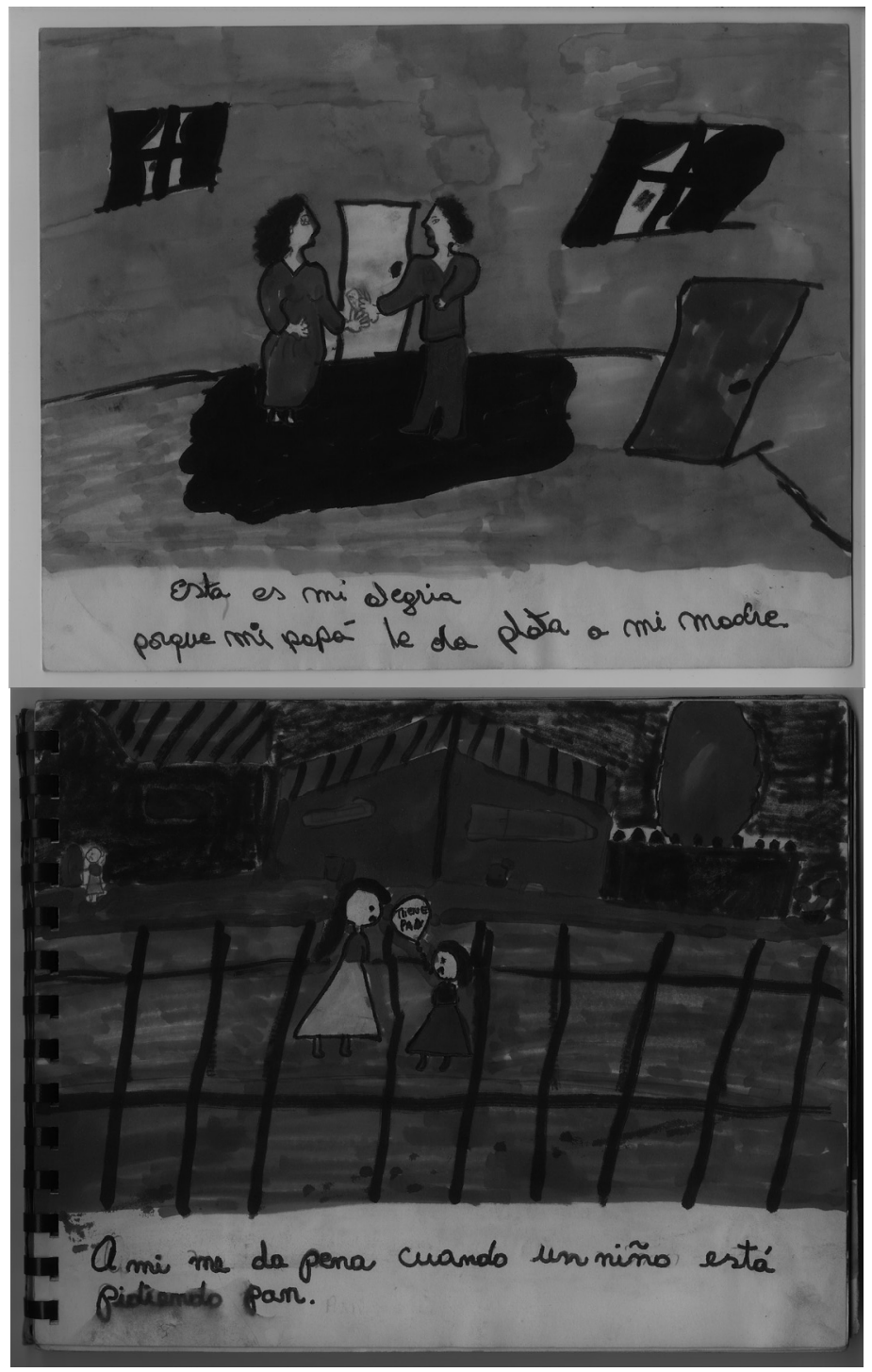

Imágenes 2 y 3. Forman parte del resultado de la sistematización del trabajo psicosocial y educativo realizado en los años ochenta por CreAs (Creacion, Educacion y Animacion Social). Esta organización ligada a los comedores infantiles, que impulsaba la vicaría de la Solidaridad en la zona oriente de Santiago. Fondo entreniños: Catálogo Infancia en dictadura. Santiago, Chile. 
el acceso a la alimentación, la educación, la salud, etc., sino que también se describen claves estéticas particulares.

Esto puede encontrarse de manera más pronunciada en una serie de dibujos realizados, en el marco de un programa de acogida a familias que retornaron del exilio durante la dictadura, por niños y niñas que venían de Europa, a los cuales la organización les solicitó dibujar los lugares de los que venían y el lugar que los recibió en su retorno: la falta de naturaleza, la presencia de contaminación, los edificios de los barrios desfavorecidos y los espacios escolares representados como cárceles son parte de lo que aparece indefectiblemente en ese tipo de retratos de la sociedad chilena (véanse imágenes 4 y 5). De algún modo, ello nos permite encontrar algo singular en la mirada infantil sobre la ciudad y el paisaje, pues su apreciación de la injusticia remite a cuestiones mucho más complejas y profundas de las que habitualmente suele suponérseles.

\section{TERRITORIO: LA NIÑEZ TÁCTICA}

Hemos definido anteriormente el territorio como una construcción históricosocial que sintetiza las relaciones de poder en un determinado espacio geográfico. Sabemos que estas relaciones pueden ser delimitadas en múltiples espacios; pero en relación con el corpus de esta investigación hemos limitado el análisis a dos instituciones que a su vez son las que con mayor frecuencia se han relacionado con la niñez: la familia y la escuela.

En otros artículos (Castillo y González 2015a; 2015b) hemos planteado algunas ideas respecto a la función filiativa, en particular de los militantes de la resistencia, es decir, de algún modo hemos hecho exceder la tradicional descripción de familia para asignar un valor político al acto de decidir tener un hijo y sostenerlo en esa función, más aún en tiempos difíciles. También en esos escritos hemos desarrollado los límites difusos de lo familiar y lo extranjero, particularmente en lo que se refiere a los activistas y militantes, es decir, la familia consanguínea en muchos de los casos de los "hijos de la resistencia" no es tan determinante como el sentido de pertenencia a una determinada comunidad política.

En este sentido, y siguiendo esta línea, es importante detenerse a analizar las producciones infantiles en cuanto describen también algo de la posición subjetiva infantil en relación con el poder generacional al que niñas y 


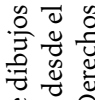

ช 0



음음

.

궁윰

छさ

च

웡

응 ญ

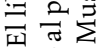

웅

ने 를

ฮี छิ

떤

응

ए

옹

응 웅



요

“थ है

造

$\circ$

훙 중

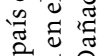

远茪

음

苛营

ㅈ.

艺 잉

च क्ष

ธี :

के 능

ปั

证

7 원

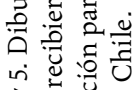

मे

\&

㐘焉

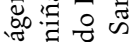

兘文

के एᄂ. 조 苯 宇

穵焉 
niños se enfrentan al interior de la institución familiar (consanguínea o no). Los bordes del territorio familiar aparecen de algún modo cuando algo de ese poder se hace explícito y amerita ser confrontado o eludido. ${ }^{5}$

Los bordes familiares pueden encontrarse en distintas partes de las producciones infantiles que componen el corpus de la investigación. Por un lado, se evidencia la rápida comprensión por parte de los niños de las adscripciones políticas de los adultos que componen ese territorio afectivo. $\mathrm{Mu}-$ chas de las producciones cuyo destinatario es alguna de las figuras familiares tienen contenidos que permiten conjeturar que se trata de una forma gráfica de reconocimiento de ese otro.

En otras producciones podemos observar el modo en que algunos niños y niñas perciben la manera en que se distribuye el poder al interior de sus núcleos familiares. Observemos la imagen que corresponde al diario de vida del año 1974 de Francisca Márquez (véase imagen 6).

Esta imagen es particularmente interesante pues permite reconocer literariamente el modo en el que esta niña percibe los bordes del territorio en que participa. Es en general en los documentos íntimos en los que podemos acceder a algo de esta reflexión, pues la mayor parte de estos razonamientos infantiles escapa a la mirada del mundo adulto, ya que se desarrollan como actos de disputa cotidiana, usualmente sin palabras, ni argumentación, interpretados como "pataletas" o "faltas a la educación". Veamos otra página del diario de Francisca Márquez, pero correspondiente al año 1973 (imagen 7).

En este texto, Francisca deja claro que a sus once años identifica perfectamente el territorio familiar y, con ello, lo que se espera de las niñas en su condición de hijas y el momento en que se distancia de esos ideales, y sus actividades se vuelven inútiles y propias de una ignorante.

En el caso de la escuela como territorio, la escena es bastante más clara, en parte porque accedemos a los documentos oficiales que permiten reconstruir los bordes del acontecimiento político denominado Dictadura, el cual resitúa los márgenes de la escuela a través de la prohibición de contenidos, la militarización de los aspectos de presentación personal e higiene, así como

${ }^{5}$ Quizás un mejor ejemplo de esta confrontación aparece en la película de Benjamín Ávila, Infancia clandestina (2011), en la escena en que el pequeño protagonista transgrede la norma que se le ha impuesto por razones de seguridad de no hacer ninguna llamada telefónica; o bien, en la película El premio (2010), de Paula Markovitch, en la que la niña, personaje principal, realiza una composición para el colegio en la que prácticamente denuncia la posición política de la familia, aun cuando llevan meses en un régimen explícito de clandestinidad. 
Secuencia, ISSN 0186-0348, edición especial

2018

pp. $119-152$

135

Querida Gaula: 24 de Lep. 1973 No lo pase tan caron como ayo queria, la caralina es mury fome. I con ella no se puede Lablan en serio. El 29 de Jep. es el santo de Nonno-: SA Wi.MI GUEG. A la hora de almuerzor la mamó y el papá nos hicièren un discurso de que eramos unas inítiles of ignorantes ete. Asi es quie. hoy dia la lela, yo, lajo isimos puras cosas de mataa y inteligente como lo consider la mamá y el papá. chac, Paula Pancha.

Imagen 7. Página correspondiente al Diario de vida de Francisca Márquez (1973). Fondo Francisca Márquez. Catálogo Infancia en dictadura. Fondecyt 11140271 Santiago, Chile, 1973. 
los sentidos patrios como eje central del currículo. Sin embargo, los documentos de los niños, particularmente los cuadernos escolares, nos permiten acceder de manera mucho más próxima tanto a los contenidos impartidos en los establecimientos, como a las divagaciones o sus formas sutiles de evasión.

En una imagen del cuaderno de Camila Estrella podemos ver un ejemplo del tipo de disciplinamiento escolar habitual del periodo; pero también el modo en que la misma desiste de realizarlo (véase imagen 8). Hay otros elementos significativos en los cuadernos escolares que permiten describir el territorio escolar: la presencia exagerada de copias de contenido religioso o acerca de los próceres de la nación (véase imagen 9); o bien, la enseñanza de la música folclórica como herramienta principal para la aproximación de los estudiantes a las bases de la construcción de la melodía y la armonía.

Por otra parte, hay otro tipo de archivos que, si bien no están creados por niños, son de sumo interés por el modo en que permiten delimitar un territorio escolar en un determinado tiempo histórico; nos referimos, por ejemplo, a las libretas de comunicación (libreta para la comunicación escrita entre padres y profesores) y a los informes de personalidad (material en general poco usado para la reconstrucción de la historia de estas instituciones) (véase imagen 10).

La escuela como un territorio habitado por la infancia se muestra como un espacio complejo en el que coinciden distintas perspectivas ideológicas y múltiples niveles de las relaciones de poder entre semejantes niños y niñas, semejantes adultos y adultos y cruzadamente.

Esto nos lleva a reflexionar respecto al modo en que se constituyen, desarrollan y transforman estas relaciones de poder en ambos espacios y nos permite dar cuenta de la hábil posición de la niñez, quienes deben desarrollar, en un breve periodo de tiempo, una serie de aprendizajes que los habilitan en las complejas maniobras de relacionarse en todos los planos con instituciones, muchas veces arbitrarias, ante las cuales se encuentran en una posición de pura subordinación.

\section{LUGARES: NIÑEZ COLECCIONISTA}

Es en el complejo espacio de las maniobras infantiles ya descritas, donde hemos de ubicar los lugares de los niños. En ese sentido, podríamos decir que el lugar de la niñez, que se describe entre los archivos que hemos recuperado, coincide con la niñez coleccionista. Walter Benjamin (1989) ya había construido ciertas orientaciones respecto a este tema: 

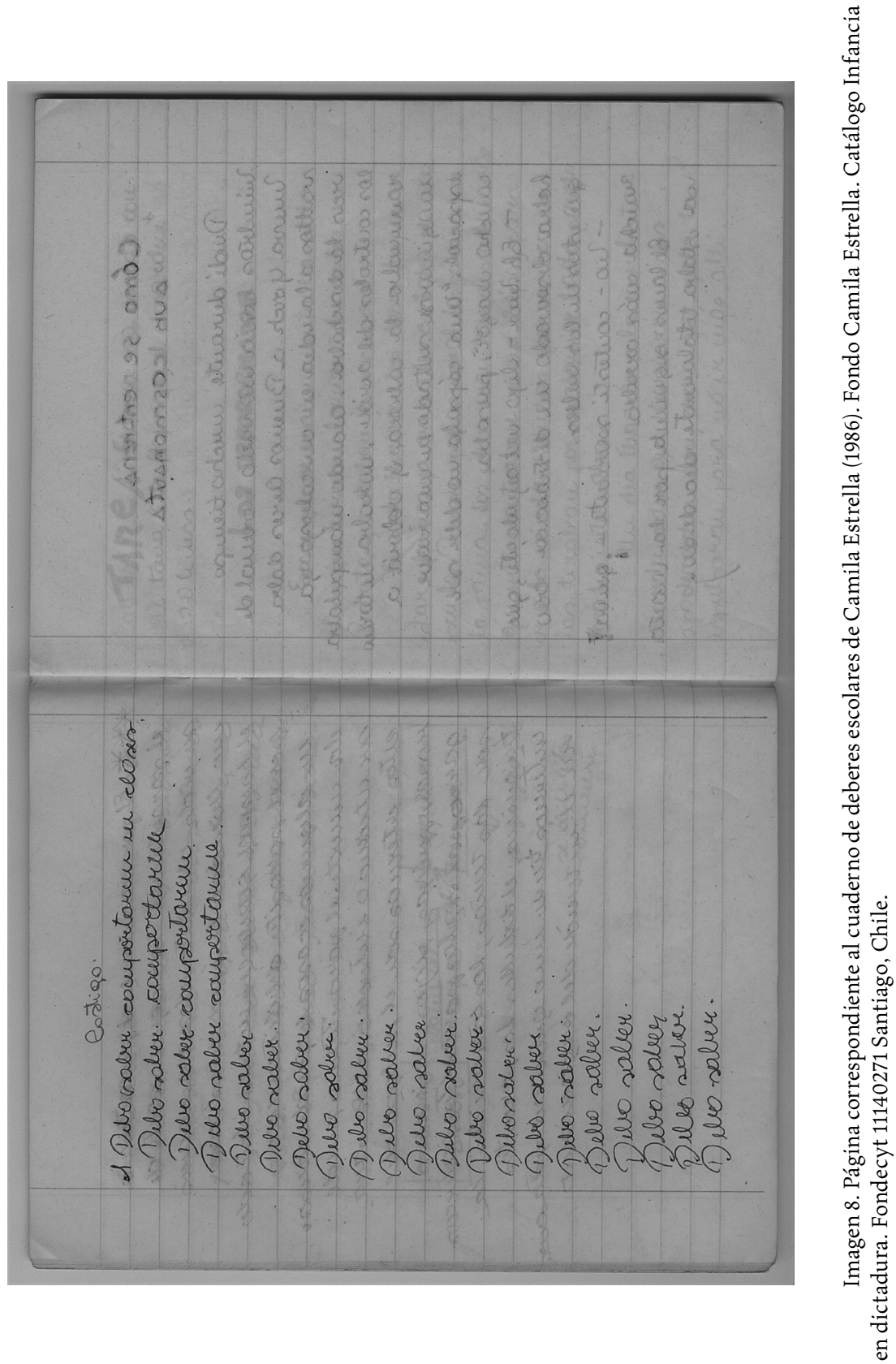


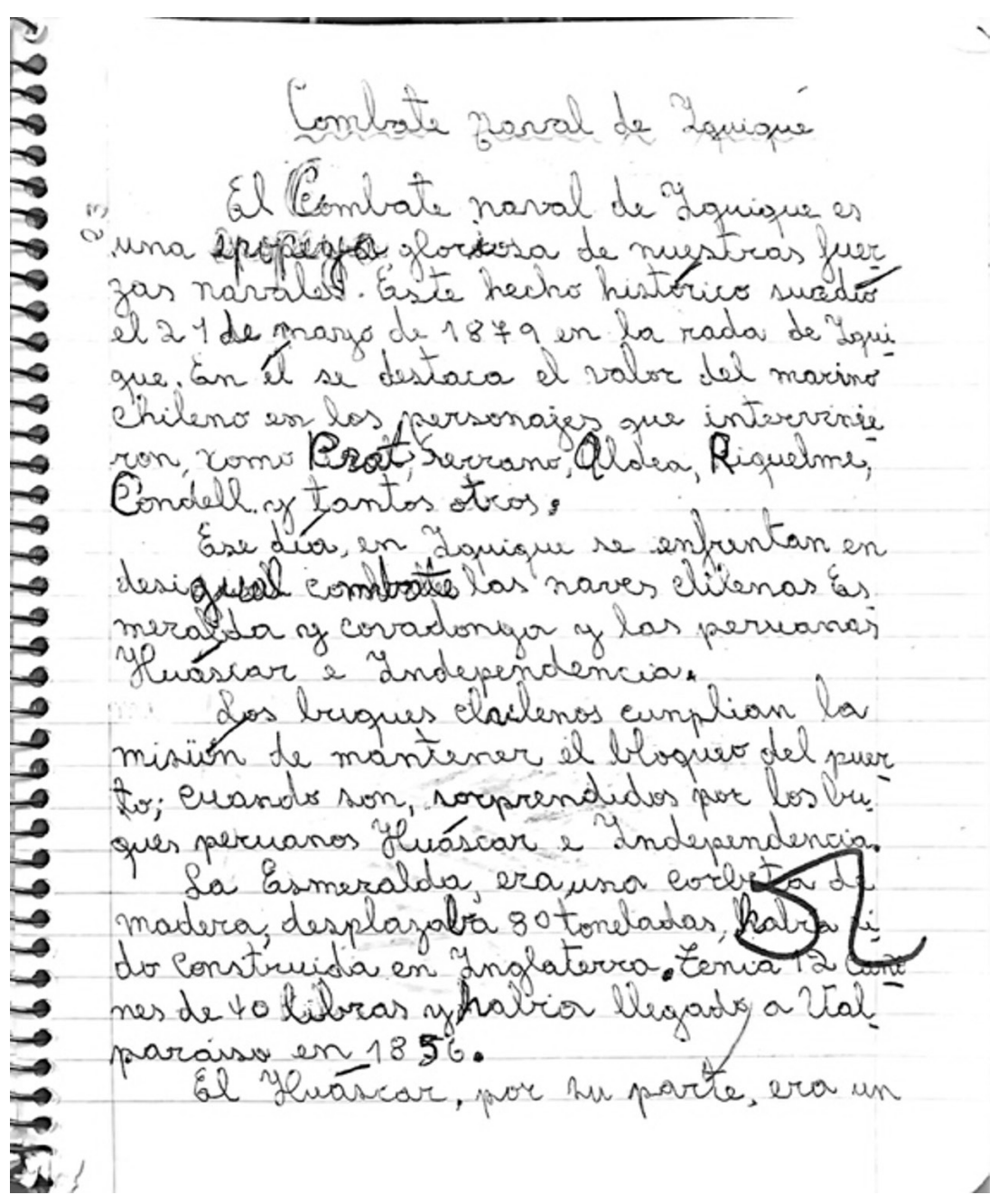

Imagen 9. Página correspondiente al cuaderno de deberes escolares de Camila Estrella (1987). Tarea de Historia. Fondo Camila Estrella. Catálogo Infancia en dictadura. Fondecyt 11140271 Santiago, Chile. 


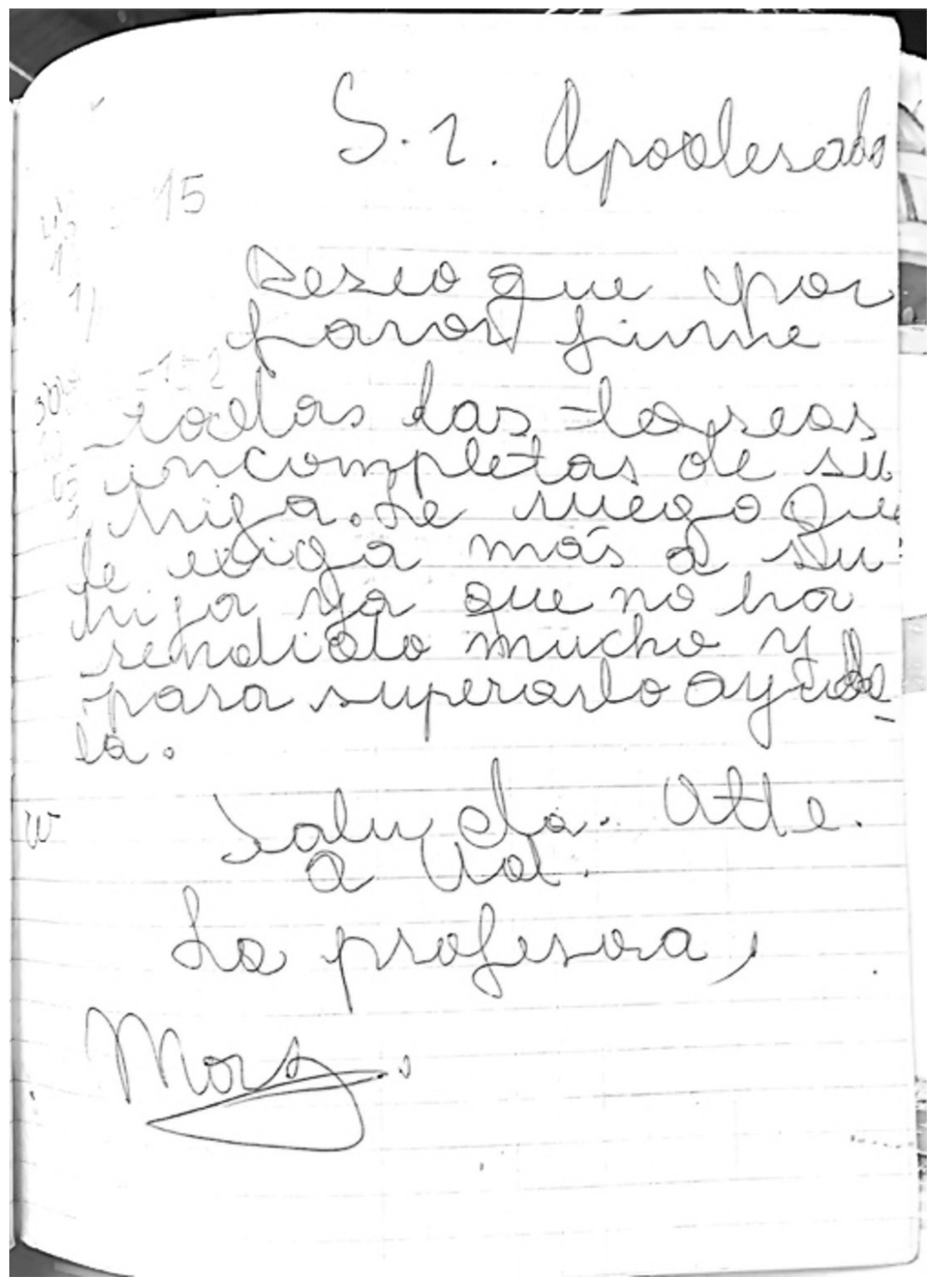

Imagen 10. Página correspondiente a la libreta de comunicaciones de Camila Estrella (1987). Fondo Camila Estrella. Catálogo Infancia en dictadura. Fondecyt 11140271 Santiago, Chile. 
La verdadera pasión del coleccionista, la que por lo general se ignora, es siempre anárquica, destructiva. Su dialéctica es combinar con la fidelidad a un objeto único, protegido por él, la porfiada y subversiva protesta contra lo típico, lo clasificable. La relación de posesión muestra acentos completamente irracionales.

Para el coleccionista el mundo está presente en cada una de sus piezas. En forma ordenada, pero ordenada de acuerdo con una relación sorprendente, más aun, comprensible para el profano. [...] Los coleccionistas son fisonomistas del mundo de los objetos (p. 122).

En ese sentido, los lugares infantiles están poblados de objetos con sentidos particulares e historizados, muchos de los cuales, pese a la importancia que los niños y niñas les asignaron en su momento, fueron perdidos u olvidados. Sin embargo, otros tantos siguen existiendo y aún conservan su estatuto sagrado. En el archivo de nuestro proyecto de investigación, muchos de esos objetos fueron entregados con la finalidad de ser inscritos en alguna parte de la historia. Es por ello que gran parte de lo que hemos recolectado puede interpretarse como un fragmento de un dialogo que estos niños y niñas sostenían con su entorno sociopolítico, con los hechos acontecidos durante la dictadura y que de algún modo fueron seleccionados como "ayuda-memoria”, o bien, como formas de inscribir aquello que por su carácter incomprensible u ominoso no pudo ser inscrito. En este sentido, nuevamente los diarios de vida son una vía privilegiada para acceder a esos fragmentos (véase imagen 11).

La imagen corresponde al diario de vida de Evelyn Moreno, respecto a este recorte que pegó en su diario, nos relató en la entrevista:

Es súper sencillo, en realidad, o sea... Es como lo que yo... escribí de lo que vi, y... que a mí me impresionó mucho, lo de los jóvenes quemados. Entonces, escribí sobre lo que pasó porque para mí fue así como "yo tengo que recordar esto", para mí fue así como "yo me tengo que acordar, yo quiero recordar los nombres de estas personas, yo no me tengo que olvidar de esto que pasó", eehh, como "tengo que siempre saber esto y cómo contarlo", como... [...] Entonces yo escribí, escribí sus nombres completos, como para saber que eso pasó y a quienes les pasó y todo. Y después, cuando salió la foto de Carmen Gloria en el diario, yo la recorté y la pegué en mi diario de vida y puse así como "Salió esta foto" (Evelyn Moreno). 


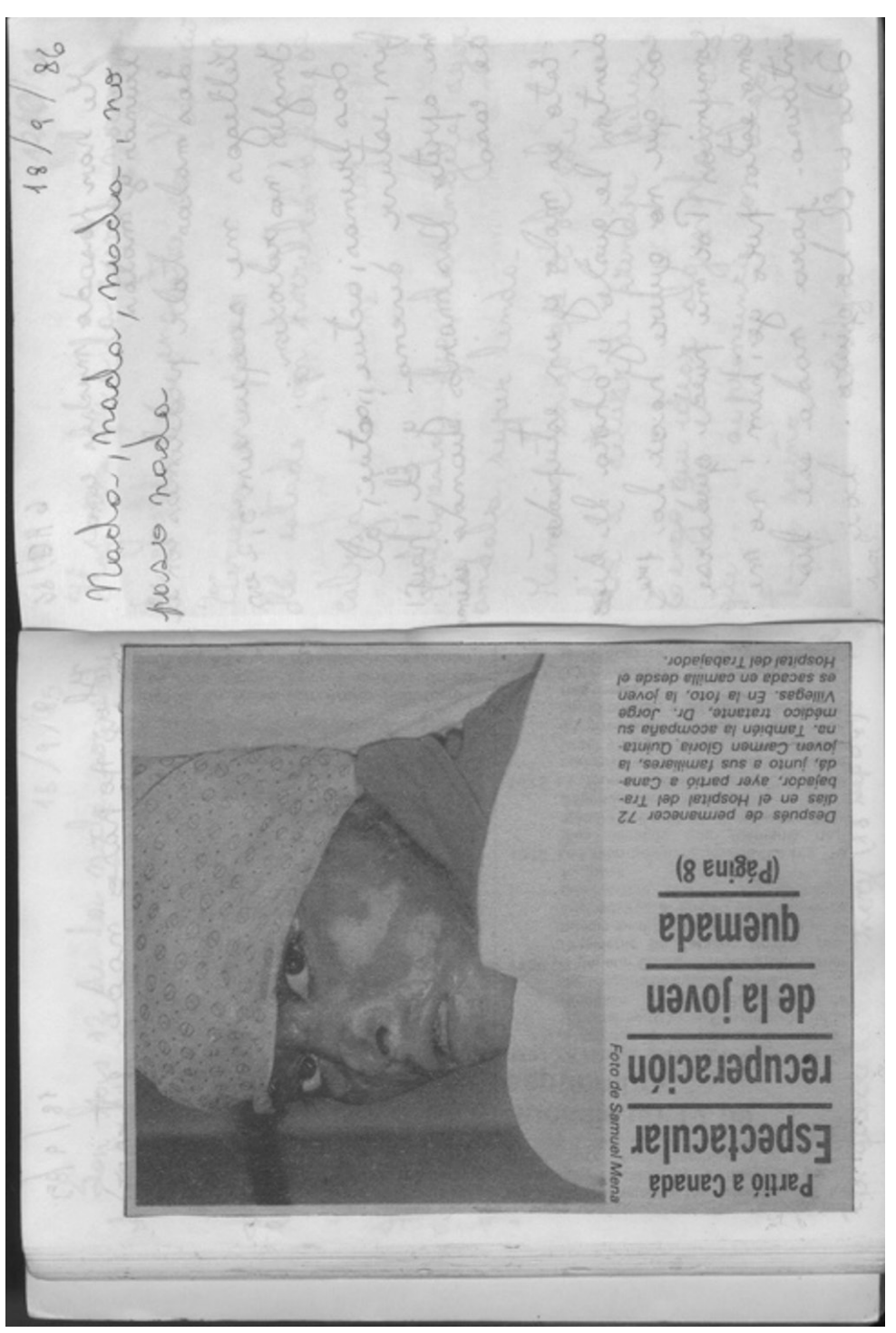

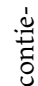

ซิ

o

.

要

एँ

코

究

骂

풀

त् प्ष

공

'ฮี तु

త

党

气ิ

ㅇ

实

$\vec{v}$

जี ت્ञ

오

อี

造

$\Xi \pi$

त.

品

。

政

도

ष

음

:

苞客

롱

20

\%

주

㫯

당

¿ क

I

ธี

䓀

छ 임

ฐ్ 
Sobre esta clase de relatos es posible encontrar más de un lugar en el que niños y niñas dirigen su escritura hacia su futuro pasado; es decir, lo interesante es que los destinatarios de estos registros son ellos mismos en el futuro, una especie de resguardo ético-político que consiste en una anotación respecto a las marcas identitarias que el territorio y el paisaje han dejado en ellos.

Asimismo hay un conjunto de archivos que describen la cultura material infantil de la época; es decir, recortes de revistas, referencias a deseos de objetos materiales o imágenes ideales que son lugarizados, es decir, se transforman en piezas de colección que remiten al proceso de construcción de una identidad espacializada en términos culturales, y cuya fragmentación permite alojar entre sus fisuras lo nuevo que puede advenir del cruce inesperado de estos elementos: la chica que fuma, la tarjetita infantil y rosada, las marcas de auto, etc. (véanse imágenes 12,13 y 14). Un solo elemento no permite entender la construcción identitaria de estos sujetos, ni el devenir futuro de sus intereses, pero sí los elementos que pugnan, se fragmentan y se combinan de forma inesperada en la colección.

De todas formas, si se pudiese establecer un tránsito cronológico de estos lugares infantiles en el tiempo estudiado es posible proponer que, conforme avanzan las edades de los niños y las niñas, va cambiando la correlación de fuerzas políticas y la resistencia contra la dictadura va organizándose de manera pública, ello se inscribe en las producciones que refieren al lugar, el lenguaje de la resistencia se torna cada vez más identificable tanto en su contenido como en los aspectos estéticos de las producciones infantiles del periodo. En los mensajes de amistad o de amor se utiliza una iconografía y lenguaje especificos que corresponden a la divulgación de consignas de las izquierdas en la época; estos mensajes no parecen tener una finalidad claramente concientizadora, sino más bien, se constituyen en un particular lenguaje del afecto y de claves para el reconocimiento entre semejantes, dando paso a la creación de lazos exogámicos de afecto en un nuevo escenario para el "nosotros" (véanse imágenes 15,16 y 17).

Es decir, los lugares infantiles hacen evidente la tensión identitaria que está implícita en el proceso de subjetivación infantil y que se sustenta en estos diálogos entre la cultura material, los sucesos del país, los ideales mediáticos y la construcción de un lenguaje cuyo destino último es la manifestación del afecto con el que se recrea un nuevo colectivo extrafamiliar. 


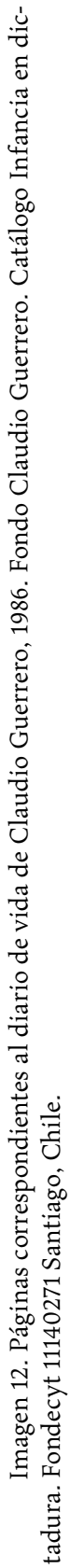




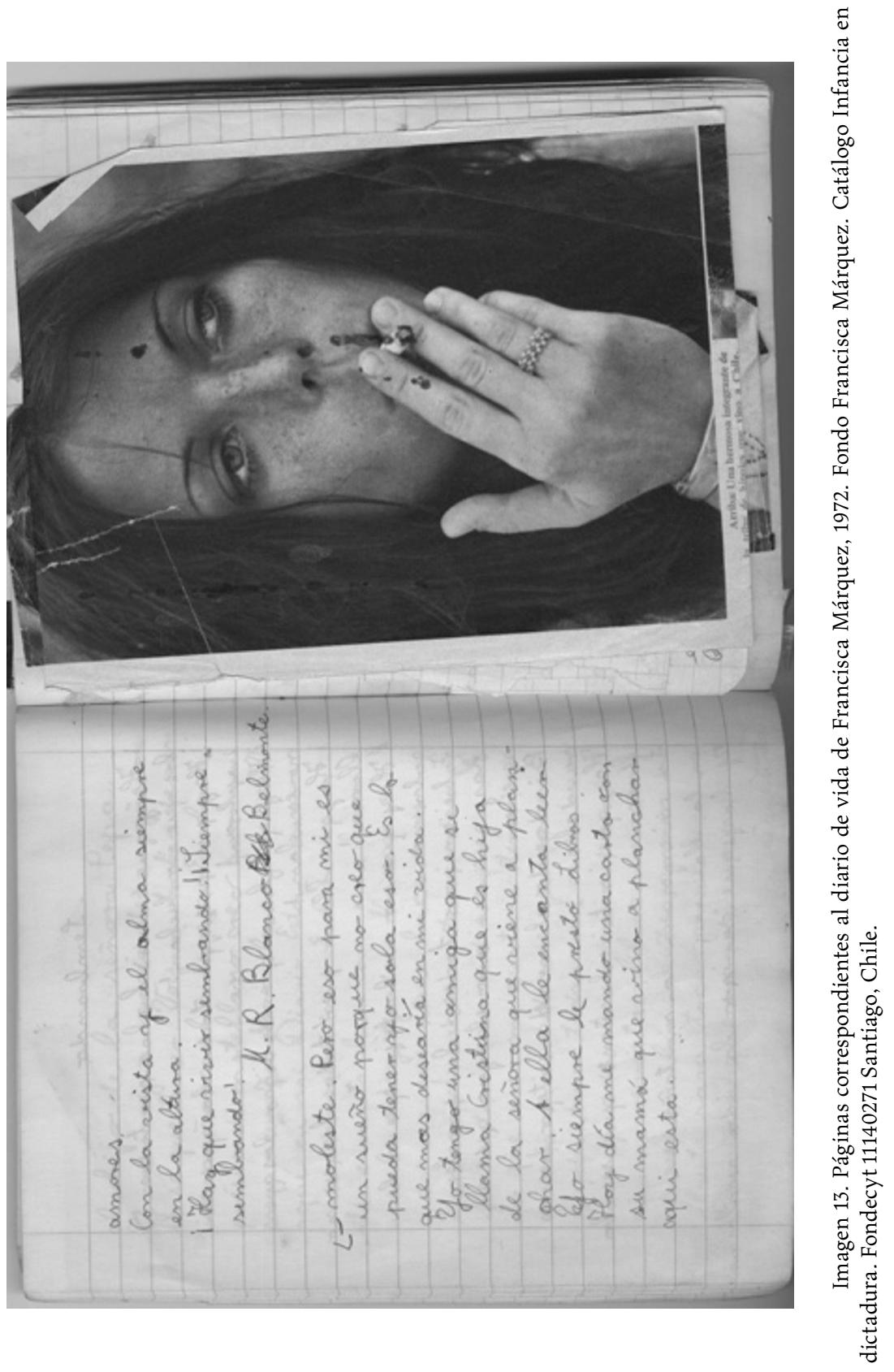




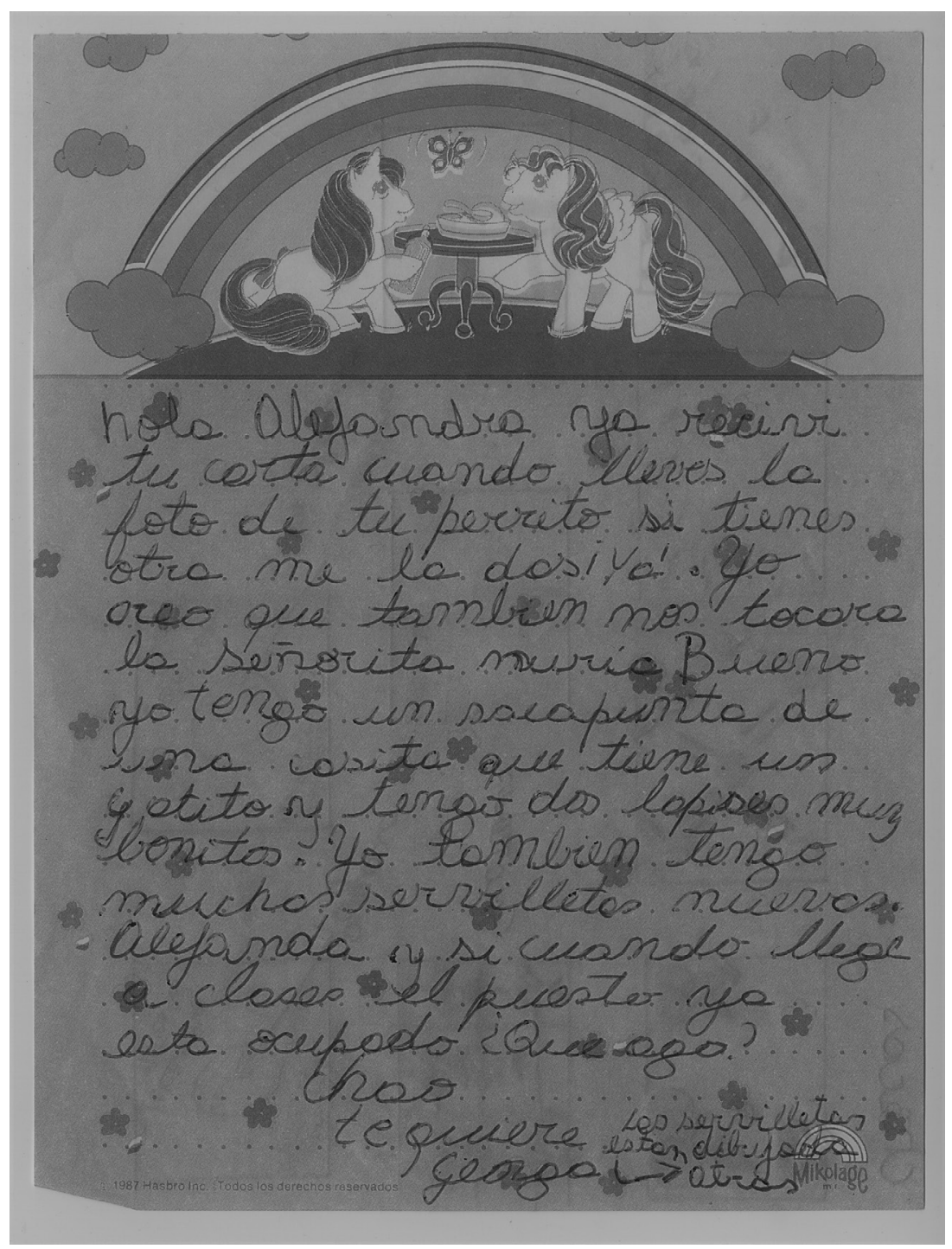

Imagen 14. Carta enviada a Alejandra González Celis por una compañera de curso, 1986. Fondo Alejandra González. Catálogo Infancia en dictadura. Fondecyt 11140271 Santiago, Chile. 




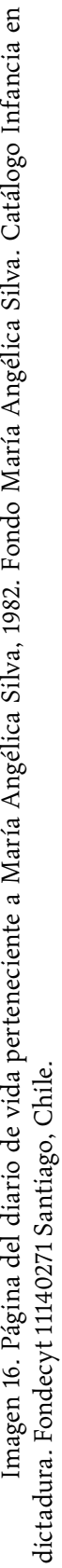




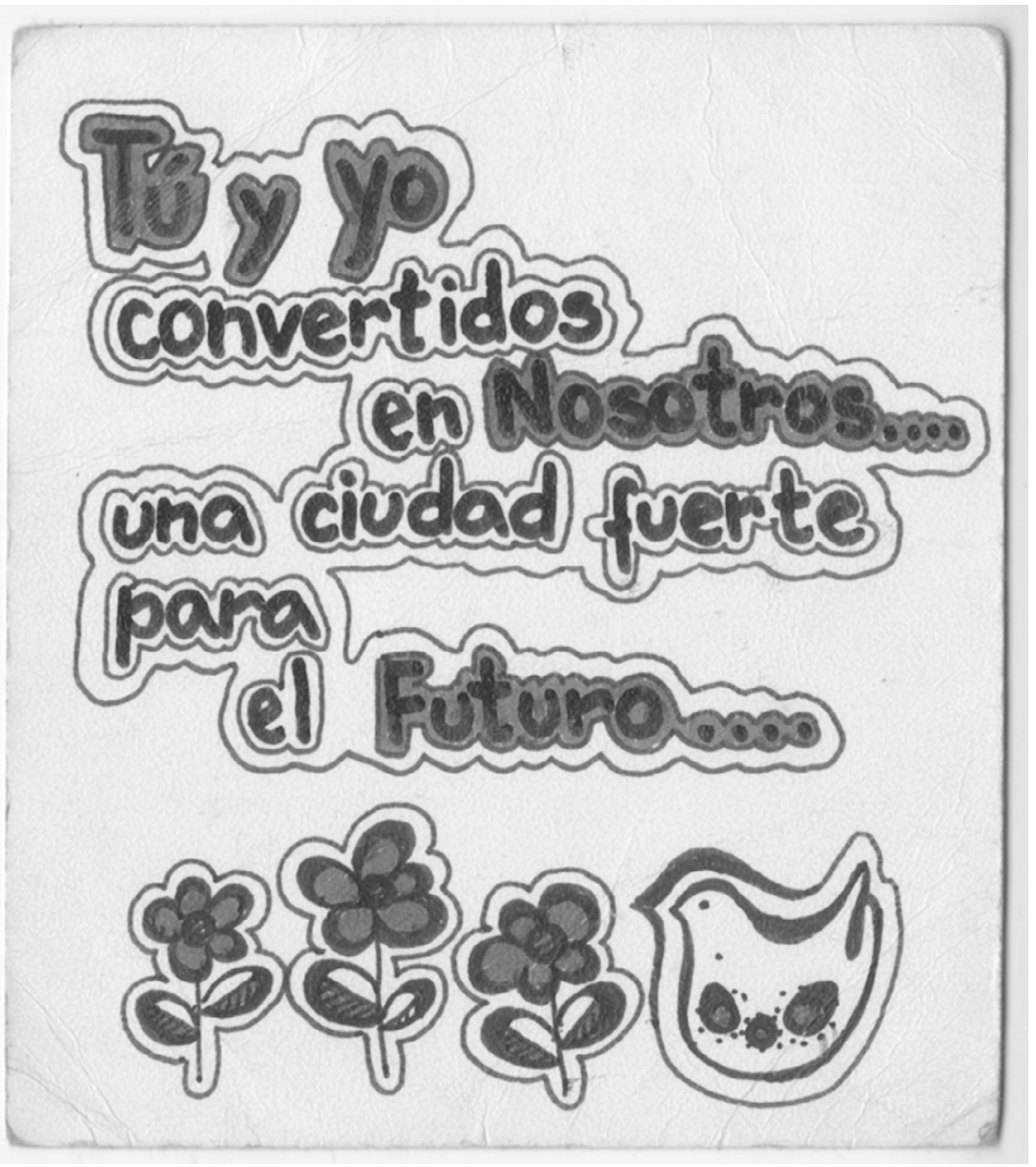

Imagen 17. Portada de tarjeta enviada a Bernarda Pérez, 1986. Fondo Bernarda Pérez. Catálogo Infancia en dictadura. Fondecyt 11140271 Santiago, Chile. 


\section{CONCLUSIONES}

Los estudios sobre las representaciones de la infancia después de la dictadura son escasos, y la mayor parte no son de carácter empírico, al menos en lo que se refiere al estudio de los significados culturales asociados a ella. Existe, por supuesto, un buen número de trabajos cuantitativos que se han preocupado por aclarar en números la realidad de la infancia en Chile; sin embargo, dichos números muchas veces estandarizan una realidad que no puede sino ser profundamente heterogénea en un país tan desigual como este.

En el tiempo de la dictadura cívico militar en Chile, como también ahora, bajo esa idealizada representación de niño y niña existe una heterogeneidad de conductas infantiles que de una u otra manera resuelven con relativa autonomía el problema de la subsistencia, la identidad y la conservación del amor del otro protector.

Los niños, en su condición de testigos, abren la posibilidad de recrear un testimonio afectivo sobre los episodios pasados y presentes cuyo valor no se encuentra en la fidelidad objetiva respecto a los hechos efectivamente acontecidos, sino más bien en que entregan una nueva luz sobre los profundos y densos procesos de habitar una determinada experiencia histórica.

En ese sentido, el distinguir el paisaje, el territorio y el lugar de la niñez durante un determinado periodo histórico es un ejercicio analítico que permite distinguir y enriquecer las perspectivas desde las cuales nos relacionamos con los espacios de la niñez, favoreciendo un encuentro entre generaciones que se instale incorporando la profundidad de estas experiencias, saliendo con ello de las lecturas más tradicionales.

\section{LISTA DE REFERENCIAS}

Abric, J.-C. (2005). La recherche du noyau central et de la zone muette des représentations sociales. En Méthodes d'étude des représentations sociales. Ramonville Saint-Agne: Érès.

Albarrán, E. (2014). Seen and heard in México. Children and revolutionary cultural nationalism. Lincoln: University of Nebraska Press.

Álvarez Vallejos, R. (2003). Desde las sombras: una historia de la clandestinidad comunista (1973-1980). Santiago, Chile: Lom Ediciones.

Arfuch, L. (2010). Sujetos y narrativas. Acta Sociológica, 53, 19-41. 
Ariès, P. (1973). L'enfant et la vie familiale sous l'Ancien Régime. Paris: Éditions du Seuil.

Benjamin, W. (1989). Escritos. La literatura infantil, los niños y los jóvenes. Buenos Aires: Ediciones Nueva Visión.

Castillo, P. (2015a). Infancia en dictadura. Niñas y niños testigos: sus producciones como testimonios. Santiago: Infancia y Memoria.

Castillo, P. (2015b). El papel del terror en la resemantización de la justicia social en Chile. En M. Castillo y C. Maldonado (eds.), Desigualdades: tolerancia, legitimación y conflicto en las sociedades latinoamericanas. Santiago: RIL Editores.

Castillo, P. y González, A. (2015a). Infancia, dictadura y resistencia: hijos e hijas de la izquierda chilena (1973-1989). Revista Latinoamericana de Ciencias Sociales, Niñez y Juventud, 13(2), 907-921. DoI: 10.11600/1692715x.13225290914

Castillo, P. y González, A. (2015b). Niñez en dictadura: lo filiativo como espacio de resistencia. Revista de Geografía Espacios, 3(6), 117-131. Recuperado de http://www. revistaespacios.cl/pdf/n6/06_castillo_espacios_06.pdf

Castillo, P. y Peña, N. (2018). Niñez como objeto del discurso de la prensa durante la dictadura chilena (1973-1989). Revista Austral de Ciencias Sociales, 32, 23-40. Recuperado de http://revistas.uach.cl/index.php/racs/article/view/1220

Castillo, P., Peña, N., Garrido, M. P., González, A. y Trujillo, F. (2017). Recuerdos de infancia: niñez y dictadura en Chile (1973-1990)/Childhood memories: chilhood and dictatorship in Chile (1973-1990). Kamchatka. Revista de Análisis Cultural, 10, 447-471. DOI: 10.7203/KAM.10.9973

Davidson, J., Bondi, L. y Smith, M. (2005). Emotional geographies. Aldershot: Ashgate. DeMause, L. (1995). The history of childhood. New Jersey: J. Aronson.

Errázuriz, L. H. (2009). Dictadura militar en Chile: antecedentes del golpe estético-cultural. Latin American Research Review, 44(2), 136-157. Dor: 10.1353/lar.0.0095

Llobet, V. (2015a). ¿Y vos qué sabés si no lo viviste? Infancia y dictadura en un pueblo de provincia. A Contracorriente: Revista de Historia Social y Literatura en América Latina, 12(3), 1-41. Recuperado de https://acontracorriente.chass.ncsu.edu/index. php/acontracorriente/article/view/876

Llobet, V. (2015b): "Y yo, ¿dónde estaba entonces?". Infancia, memoria y dictadura. Horizontes Sociológicos, 3(5), 46-57. Recuperado de http://aass.org.elserver.com/ojs/ index.php/hs/article/view/28

Magasich-Airola, J. (2008). Los que dijeron "No": historia del movimiento de los marinos antigolpistas de 1973. Santiago, Chile: LOM Ediciones.

Massey, D. (2004). Lugar, identidad y geografías de la responsabilidad en un mundo en proceso de globalización. Treballs de la Societat Catalana de Geografia, 57, 77-84. Recuperado de http://revistes.iec.cat/index.php/TSCG/article/view/54650 
Milos, P. (2007). Historia y memoria: 2 de abril de 1957. Santiago, Chile: Lom Ediciones. Moyano Barahona, C. (2009). MAPU o la seducción del poder y la juventud: los años fundacionales del partido-mito de nuestra transición (1969-1973). Santiago, Chile: Ediciones Universidad Alberto Hurtado.

Nogué, J. (2014). Sentido del lugar, paisaje y conflicto. Geopolítica (s). Revista de Estudios sobre Espacio y Poder, 5(2), 155-163. DoI: 10.5209/rev_GEOP.2014.V5.N2.48842

Palma Salamanca, R. (1997). El gran rescate: desflorando al viento. Santiago, Chile: LOM Ediciones.

Pollock, L. A. (1990). Los niños olvidados: relaciones entre padres e hijos de 1500 a 1900. México: Fondo de Cultura Económica.

Potter, J., Wetherell, M. y Wetherell, P. M. (1987). Discourse and social psychology: Beyond attitudes and behaviour. Thousand Oaks, CA: Sage Publications.

Rebolledo, J. (2012). La danza de los cuervos: el destino final de los detenidos desaparecidos. Santiago, Chile: Ceibo Ediciones.

Riché, P. y Alexandre-Bidon, D. (2005). La vie des enfants au Moyen Âge. Paris: Éditions du Sorbier.

Rodríguez, P. y Mannarelli, M. E. (2007). Historia de la infancia en América Latina. Bogotá, Colombia: Universidad Externado de Colombia.

Rojas Flores, J. (2010). Historia de la infancia en el Chile republicano, 1810-2010. Santiago, Chile: Ocho Libros.

Rousso, H. (2012). Para una historia de la memoria colectiva: El post-Vichy. Aletheia: Revista de la Maestría en Historia y Memoria de la FaHCE, 3(5), 1-14. Recuperado de http://www.aletheia.fahce.unlp.edu.ar/numeros/numero-5/traducciones/parauna-historia-de-la-memoria-colectiva-el-post-vichy

Salazar, G. (2006). Ser niño "huacho" en la historia de Chile (siglo XIX). Santiago, Chile: LOM Ediciones.

Sandoval Ambiado, C. (2004). Movimiento de Izquierda Revolucionaria 1970-1973. Coyunturas, documentos y vivencias. Concepción: Ediciones Escaparate.

Santos, Milton (2000). La naturaleza del espacio geográfico. Técnica y tiempo; razón y emoción. Barcelona: Ariel Geografía.

Simarro, C. (2015). Diario de una niña en tiempos de guerra y exilio (1938-1944) (edición de S. Sosenski). México-Madrid: Universidad Nacional Autónoma de México/ Universidad Nacional de Educación a Distancia.

Sosenski, S. (2005). Guardianes de la memoria. La conmemoración del golpe militar entre los exiliados argentinos en México. Economía, Sociedad y Territorio, v(18), 377409. DoI: $10.22136 /$ est002005310 
Sosenski, S. (2010). Niños en acción. El trabajo infantil en la ciudad de México (19201934). México: El Colegio de México.

Sosenski, S. (2012). Producciones culturales para la infancia mexicana: los juguetes (1950-1960). Relaciones. Estudios de Historia y Sociedad, 33(132), 95-126. Recuperado de http://www.scielo.org.mx/pdf/rz/v33n132/v33n132a4.pdf

Sosenski, S. (2016). Dar casa a las voces infantiles, reflexiones desde la historia. Revista Latinoamericana de Ciencias Sociales, Niñez y Juventud, 14(1), 43-52. DoI:10.11600 /1692715x.1411250315

Sosenski, S., y Albarrán, E. C. (2012). Nuevas miradas a la historia de la infancia en América Latina: entre prácticas y representaciones. Ciudad de México: Universidad Nacional Autónoma de México.

Souza, M. J. L. D. (1995). O território: sobre espaço e poder, autonomia e desenvolvimento. Geografia: conceitos e temas. Rio de janeiro: Bertrand Brasil, 77-116.

Tuan, Y. (2007). Topofilia (Trad. al castellano por F. Durán de Zapata). Barcelona: Melusina.

Valdivia Ortiz de Zárate, V. (2006). Su revolución contra nuestra revolución: La pugna marxista-gremialista en los ochenta (Vol. 2). Santiago, Chile: Lom Ediciones

Valdivia Ortiz de Zárate, V. (2010). ¡Estamos en guerra, señores!: El régimen militar de Pinochet y el "pueblo", 1973-1980. Historia (Santiago), 43(1), 163-201. DoI: 10.4067/S0717-71942010000100005

Verdejo, R. M., Maureira, G., Dalla Porta, M. T. (2014). Memoria y archivo oral: hijos e hijas de detenidos desaparecidos [Memory and oral archive: Children of missing detainees]. Santiago, Chile: Fundación PIDEE.

Verdejo, R., Maureira R. y Dalla Porta, F. (2015). El arte de narrar en la construcción de la memoria: niñas, niños y jóvenes en el exilio. Santiago de Chile: Fundación PIDEE/ Embajada de Finlandia/Museo de la Memoria y los Derechos Humanos.

Vidaurrázaga Aránguiz, T. (2006). Mujeres en rojo y negro: reconstrucción de la memoria de tres mujeres miristas, 1971-1990. Concepción: Escaparate Ediciones. 